\title{
DETECTION AND NEUTRALIZATION OF VENOM BY OVINE ANTISERUM IN EXPERIMENTAL ENVENOMING BY Bothrops jararaca
}

\author{
PERES C. M. (1), BASTOS M. F. (1), FERREIRA J. (2), SARTORI A. (1)
}

(1) Department of Microbiology and Immunology, Institute of Biosciences, São Paulo State University, UNESP, Botucatu, São Paulo, Brazil; (2) São Carlos Institute of Physics, University of São Paulo, USP, São Paulo, Brazil.

\begin{abstract}
In this study we optimized an enzyme-linked immunosorbent assay (ELISA) to evaluate bothropic venom levels in biological samples. These samples were obtained by two distinct protocols. In the first one, Swiss mice were injected with $1 \mathrm{LD}_{50}$ of Bothrops jararaca (B. jararaca) venom and 15 minutes later, animals were treated with ovine antibothropic serum. Blood and spleen homogenate samples were obtained 6 hours after antiserum therapy. Ovine antibothropic serum significantly neutralized venom levels in serum and spleen. In the second protocol, BALB/c mice were injected with $1 \mathrm{LD}_{50}$ of bothropic venom by either intraperitoneal (IP) or intradermal (ID) route and venom levels were evaluated 1, 3 and 6 hours after, in blood, spleen homogenates and urine. Serum and splenic venom levels were significantly higher in animals envenomed by IP route comparing with animals envenomed by ID route. Higher venom levels were also detected in urine samples from animals envenomed by IP route. However, these differences were not statistically significant. These results demonstrated that the optimized ELISA was adequate to quantify venom levels in different biological samples. This assay could, therefore, substitute the in vivo neutralizing assay and also be useful to evaluate the severity of human and experimental envenomations.
\end{abstract}

KEY WORDS: Bothrops jararaca, enzyme-linked immunosorbent assay, ovine antibothropic serum, venom neutralization.

\section{CORRESPONDENCE TO:}

ALEXANDRINA SARTORI, Departamento de Microbiologia e Imunologia, Instituto de Biociências, Universidade Estadual Paulista, UNESP, Botucatu, São Paulo, Brasil, 18618-000. Phone: +55 143811 6058. Fax: +55 143815 3744. E-mail: sartori@ibb.unesp.br. 


\section{INTRODUCTION}

About 20,000 cases of snakebites are reported annually in Brazil, with a mortality rate of $0.5 \%$ (8). Bothrops jararaca is the species responsible for the majority of snakebites in southeast Brazil (20).

The most effective therapy to counteract toxic effects of ophidic venoms is treatment with specific antiserum produced in horses. However, this kind of therapy can be associated with side effects as type I and III hypersensitivities (15). Alternative antibody sources, devoid of deleterious effects, are highly desirable. Sjostram et al. (21) compared monospecific antivenoms raised in sheep against a variety of snake venoms with commercially available antisera. They observed that ovine antivenoms generally contained higher concentration of specific antibodies than equine derived material. In addition, the ovine product usually provided better in vivo protection to mice than the equine counterpart (21). Easier ovine management, comparing to equines, has also stimulated sheep usage to generate antivenoms. Antisera to different snake venoms have been raised in sheep by Instituto Clodomiro Picado, including antiserum against Bothrops asper $(13,14,19,24)$.

Efficiency and safety in venom immunotherapy have also been improved by application of enzyme-linked immunosorbent assay (ELISA) to snake venom research. Theakston et al. (22) first described the use of this assay in detection of antigen and antibody in snake bitten patients. Subsequently, ELISAs have been described for detection of venom antigens from different species of venomous animals $(3,10,11,12,23)$.

In this study, we reported the development of a sandwich-type ELISA for detection of $B$. jararaca venom antigens in blood, spleen homogenate and urine of mice experimentally envenomed by two different routes. We also used this assay to evaluate the in vivo ability of an ovine antibothropic serum to neutralize serum venom levels.

\section{MATERIALS AND METHODS}

\section{Venom}

A pool of lyophilized venoms was obtained from various adult specimens of Bothrops jararaca snakes kept at the Center for the Study of Venoms and Venomous Animals 
(CEVAP, UNESP, Botucatu, São Paulo). After lyophilization, the material was stocked at $-40^{\circ} \mathrm{C}$. For usage, the venom was diluted in endotoxin free salt solution.

\section{Animals}

Male Swiss mice, female BALB/c mice, aged 4-6 weeks, and two female Norfolk rabbits (Botucatu Strain, 2-3kg) were supplied by the Central Animal Facility of São Paulo State University, UNESP, Botucatu, São Paulo. The animals were kept at the Animal Facility of the Department of Microbiology and Immunology throughout the experiments with free access to food and water. Four ovines of ideal breed (65-70kg), aged 3-11 years old, were kept at the Veterinarian Hospital at UNESP, Botucatu.

\section{Antibodies}

Peroxidase-conjugated goat anti-rabbit immunoglobulin antibody was purchased from Sigmal Chemical Co. Antibothropic serum was obtained by rabbit immunization. Animals were initially injected with $250 \mathrm{ng}$ of $B$. jararaca venom emulsified with $0.5 \mathrm{ml}$ of Complete Freund's Adjuvant (CFA), by subcutaneous (SC) route. Three other doses of 100ng emulsified with $0.5 \mathrm{ml}$ of Incomplete Freund's adjuvant (IFA) were delivered by SC route. Time interval among inoculations was 10 days. Two weeks after the last dose, animals were bled and serum kept at $-20^{\circ} \mathrm{C}$ until use.

The ovine antibothropic serum was obtained by following the procedures developed at Instituto Clodomiro Picado (7). Briefly, 4 animals were immunized with seven doses of bothropic venom. The following doses: $0.5 ; 1 ; 3 ; 9 ; 18 ; 30$; and $45 \mathrm{mg}$ were injected by SC route on days $0 ; 15 ; 30 ; 40 ; 50 ; 60$; and 70 , respectively. The first dose was associated with CFA, the second one with IFA, and the remaining doses with $\mathrm{Al}(\mathrm{OH})_{3}$. Booster effect on antiserum levels was measured by an indirect ELISA. The antiserum used in this investigation was obtained from one animal (N.1572), whose maximum title was observed 30-40 days after the first immunization. Further boosters did not significantly affect the specific antibody level. The last antibody sample, obtained 10 days after the last venom dose, was used due to its expected higher affinity. 


\section{Blood, urine and spleen homogenates}

Initially, Swiss mice were used to evaluate the neutralizing ability of the ovine antiserum. Animals were allocated in 4 groups (5 animals each). Each group received $2.5 \mu \mathrm{g} / \mathrm{g}$ of bothropic venom by IP route. After 15 minutes, three of these groups were treated with ovine antibothropic serum (diluted 1:10, 1:40, or 1:200). The fourth group was left untreated to be used as a control. Treatment was delivered in a $200 \mu l$ final volume. After six hours animals were killed and blood and spleen were collected. Blood samples were obtained by cardiac puncture and spleen homogenates were prepared by disrupting the splenic tissue on a sterile fine nylon screen with 500 $\mu$ l of RPMI 1640 medium. Blood samples and splenic homogenates were centrifuged and supernatants stored at $-20^{\circ} \mathrm{C}$ for further venom quantification by ELISA.

To assess the relationship between envenomation route and venom levels, BALB/c mice were injected with $2.5 \mu \mathrm{g} / \mathrm{g}$ of bothropic venom by either IP or ID (footpad) route. After 1 , 3 and 6 hours, groups of animals were killed and blood, urine and splenic homogenates were also obtained, centrifuged and stocked at $-20^{\circ} \mathrm{C}$ for further evaluation. Samples obtained in a similar way from non-envenomed animals were used as controls.

\section{ELISA for venom quantification}

This assay was standardized according to Barral-Netto et al. (3) and also to our previous experience in this field (4). Polypropylene microtiter plates were coated with $F\left(a b^{\prime}\right)_{2}$ fraction from horse anti-B. jararaca venom (batch n. 970802, produced by Instituto Vital Brazil, Niterói, Rio de Janeiro) (100 $\mu$ l diluted 1:200 in carbonate-bicarbonate buffer, pH 9.6, for $1 \mathrm{~h}$ at $37^{\circ} \mathrm{C}$ ). The wells were then washed five times with $200 \mu$ l phosphate buffered saline (PBS) containing 0.05\% Tween 20 (PBS-T) and incubated overnight at $4^{\circ} \mathrm{C}$ with $3 \%$ low-fat milk in carbonate-bicarbonate buffer as a blocking step. After another washing cycle, a 2-h incubation was performed with either various concentrations of $B$. jararaca venom (ranging from $65 \mathrm{ng} / \mathrm{ml}$ to $500 \mathrm{pg} / \mathrm{ml}$ ) or samples from serum, splenic homogenates or urine. Each venom concentration was tested in duplicate. After another washing step, $100 \mu \mathrm{l}$ of rabbit antibothropic serum (1:200) was added to the plate and incubated $1 \mathrm{~h}$ at $37^{\circ} \mathrm{C}$. The wells were subsequently washed and $100 \mu$ l of goat anti-rabbit IgG conjugated to peroxidase (1:8000) were added. The plates 
were incubated for $1 \mathrm{~h}$ at $37^{\circ} \mathrm{C}$. The wells were then washed and incubated with $100 \mu \mathrm{l}$ of an enzimatic substrate containing $0.04 \%$ ortho-phenylenediamine plus $0.012 \%$ hydrogen peroxide in citrate-phosphate buffer $(\mathrm{pH} 5.0)$ for about $15 \mathrm{~min}$ at room temperature in the dark. The reaction was stopped by addition of $50 \mu \mathrm{l}$ of $2 \mathrm{M}$ sulfuric acid and the absorbance values were measured at 492nm using an ELISA reader (Multiskan Spectrophotometer, manufactured in Finland by Labsystems). Venom concentrations were interpolated from standard curves of $B$. jararaca venom.

\section{RESULTS}

\section{ELISA optimization for Bothrops jararaca venom detection}

The best conditions for $B$. jararaca venom detection included a blocking step $(12 \mathrm{~h}$ at $4^{\circ} \mathrm{C}$ ) with a carbonate/bicarbonate buffer $(\mathrm{pH} 9.6)$ containing $3 \%$ non-fat dry milk. Specificity was increased by this procedure. Samples incubation during $2 \mathrm{~h}$ at $37^{\circ} \mathrm{C}$ also increased sensitivity $(500 \mathrm{pg} / \mathrm{ml})$. The best dilution for horse $F\left(a b^{\prime}\right)_{2}$ used as capture antibody and for detection antibody (whole rabbit antibothropic serum) was 1:200. The best dilution for the conjugate (goat anti-rabbit serum) was 1:8000. The best incubation condition for these three antibodies was $1 \mathrm{~h}$ at $37^{\circ} \mathrm{C}$. The correlation coefficient $(r)$ of this assay varied from 0.96 to 0.98 . By using these conditions we were able to detect very low levels of bothropic venom in biological samples. A titration curve done with a crude preparation of venom from $B$. jararaca is shown in Figure 1.

\section{Neutralizing activity of ovine antibothropic serum}

As can be observed in Figure $2 \mathrm{a}$, ovine antiserum administration determined a significant drop on serum venom levels. The neutralization effect was, as expected, more pronounced with less diluted serum. On the other hand, when spleen homogenates were used to evaluate venom concentration (Figure $2 b$ ), only animals that received the less diluted ovine antiserum (1:10) presented a significant decrease in venom concentration. 


\section{Comparison of venom levels in mice envenomed by IP or ID route}

As shown in Figure $3 a$, serum venom levels were significantly higher in animals that were envenomed by IP route in comparison with animals envenomed by ID route. This difference was observed at the three evaluation periods.

A similar pattern of venom concentrations was observed in urine (Figure $3 b$ ) and spleen homogenate (Figure 3c) samples. In spite of this similarity, differences observed in urine samples were not statistically significant.

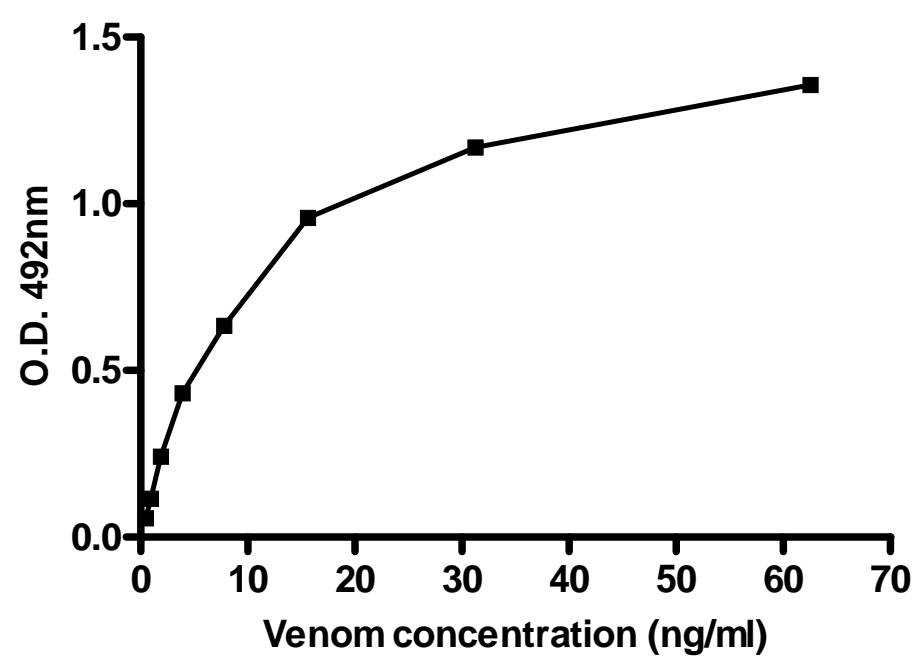

Figure 1: ELISA representative calibration curve for $B$. jararaca crude venom detection. Venom was diluted with PBS/milk 3\% and ELISA developed with the reagents described before. Resulting optical densities were correlated to venom concentrations. Optical densities from three separate assays were combined $(n=6)$ and showed in mean \pm SD. The $r$ value is 0.98 . 

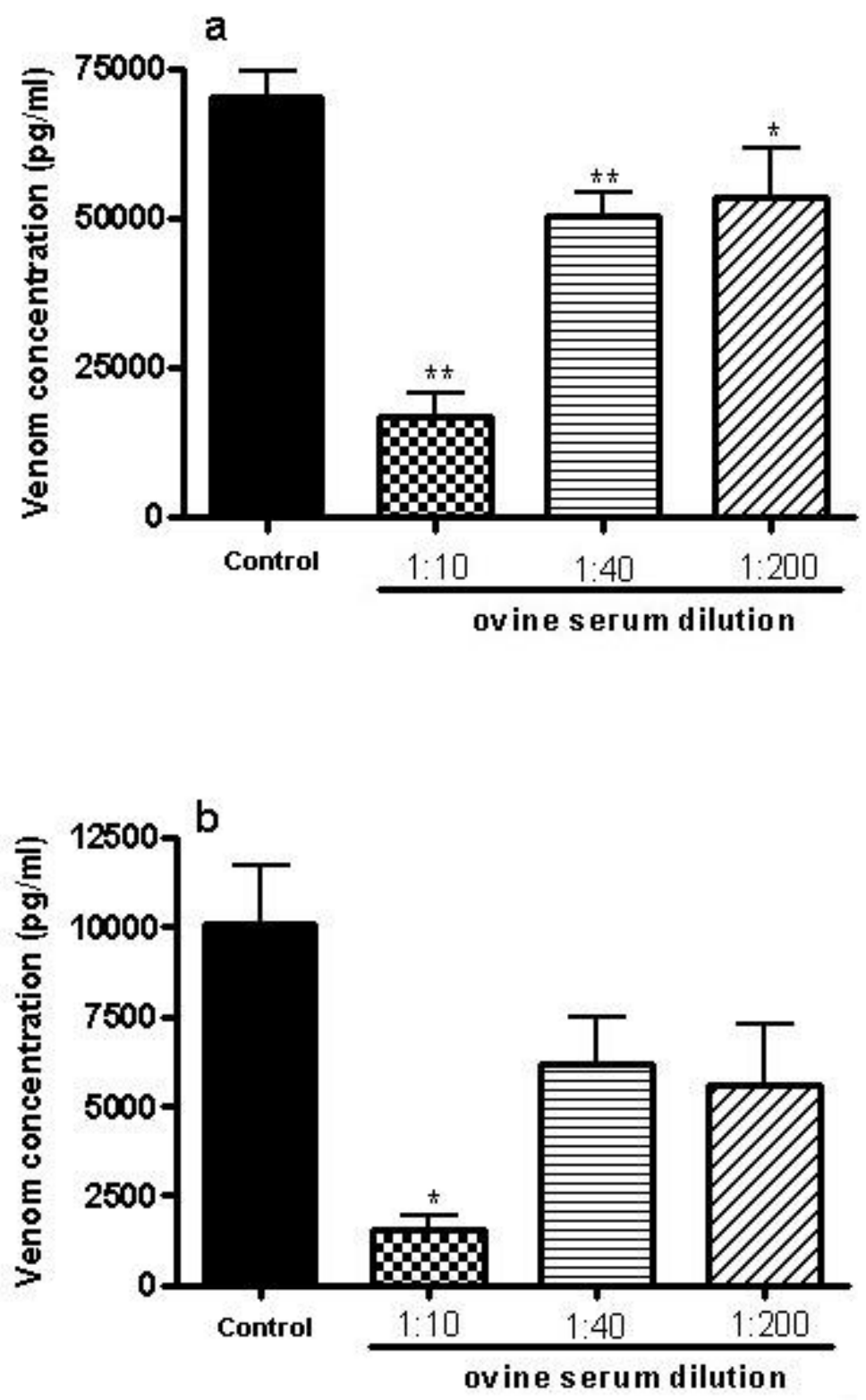

Figure 2: In vivo neutralizing activity of ovine antibothropic serum. Swiss mice were injected with $1 L^{L 0}$ of $B$. jararaca venom by IP route. After $15 \mathrm{~min}$, animals were treated with ovine antibothropic serum (diluted 1:10, 1:40, or 1:200). A group was left untreated and used as a control. Biological samples were obtained 6 hours after venom inoculation and analyzed for their venom concentration by ELISA. Venom concentrations in blood (a) and spleen homogenate (b) samples. Values are means \pm SD. ${ }^{*} p<0.05$ and ${ }^{* *} p<0.01$ regarding the untreated group. 


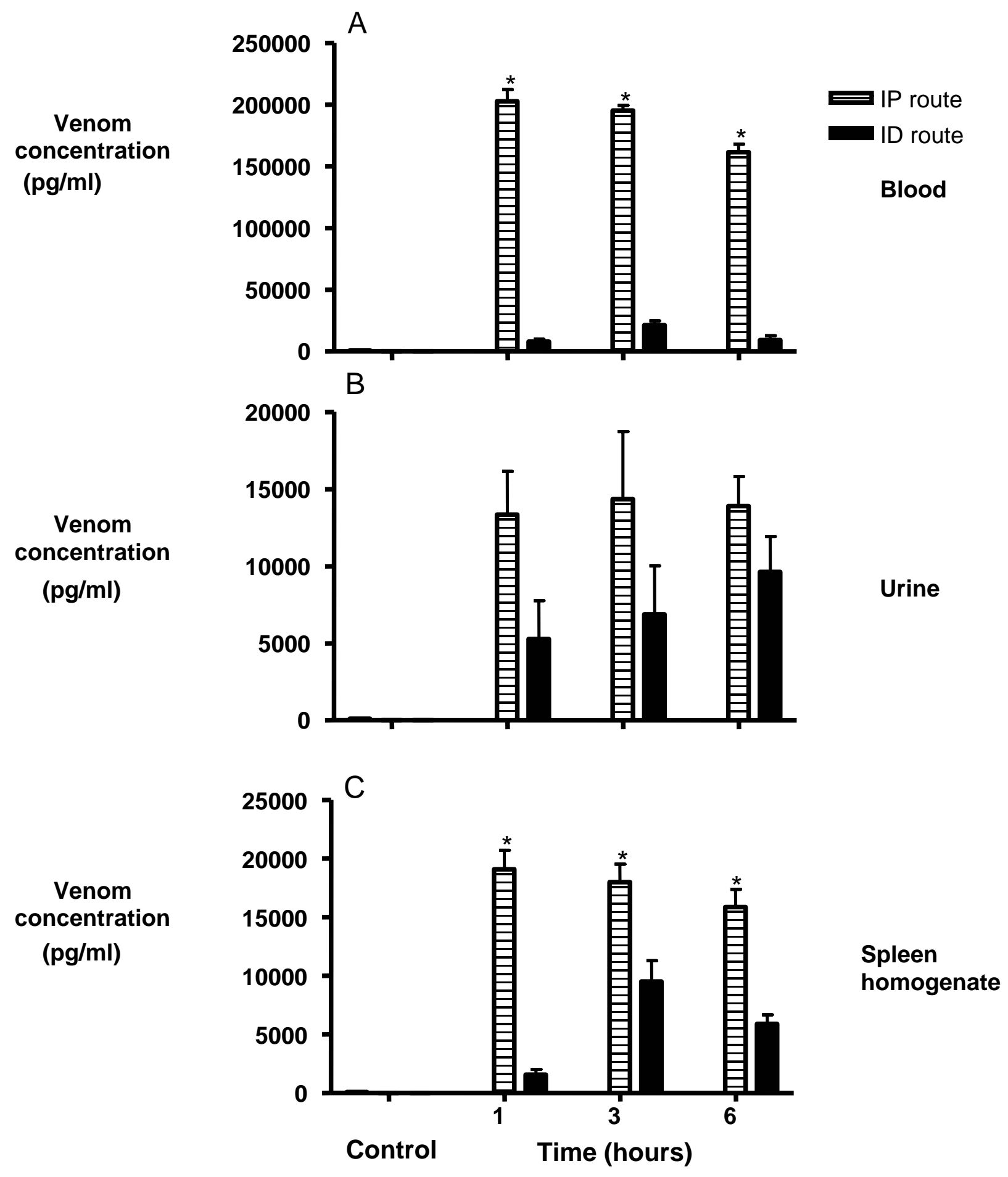


Figure 3: Venom concentrations in biological samples. BALB/c mice were injected with 1 $\mathrm{LD}_{50}$ of $B$. jararaca venom by either IP or ID route and biological samples were obtained 1, 3, and 6 hours after inoculation. Samples were analyzed for their venom concentrations by ELISA. Venom concentrations in blood (a), urine (b) and spleen homogenate (c) samples. Values are means \pm SD. ${ }^{*} \mathrm{p}<0.05$ regarding ID route at the same period.

\section{DISCUSSION}

Among the ophidian accidents occurring in Botucatu area, located at São Paulo State, about $80 \%$ are caused by Bothrops species (6). As in many other parts of the world, treatment is still based on inoculation of horse antibothropic serum (12). There is an increasing interest for development of other sources of antivenom and also of assays to identify the venom and its concentration in body fluids. This investigation was done to develop a sandwich-type ELISA for detection and comparison of venom levels in blood, urine and spleen homogenate samples obtained from mice experimentally injected with bothropic venom. This methodology was also employed to evaluate the neutralizing ability of an ovine anti-Bothropic antivenom.

The ELISA test adapted by us presented elevated sensitivity $(500 \mathrm{pg} / \mathrm{ml})$, similar to values described in other reports $(1,3,18)$. The blocking step done by using non-fat milk during $12 \mathrm{~h}$ at $4^{\circ} \mathrm{C}$ comparing with $1 \mathrm{~h}$ at room temperature was very effective, decreasing substantially the background. The usefulness of this step to improve the specificity was not evaluated. We believe that sensitivity and specificity could be improved by substituting the whole rabbit anti-bothropic serum for its IgG fraction. Once optimized, this assay was used to quantify venom in biological samples from experimentally envenomed mice.

Initially, it was observed that non-diluted sheep antibothropic venom was able to neutralize lethal venom activity associated with 2 LD $_{50}$ (not shown). The potency of antivenom has been traditionally evaluated by testing lethality neutralization (25). As this procedure requires sacrifice of a large number of mice, other alternatives are being sought to replace the in vivo neutralization assay. For this reason, this neutralizing ability was then checked by quantification of serum and splenic venom levels by ELISA. 
According to the neutralizing effect observed in vivo, serum and splenic venom levels were significantly lower in animals subjected to ovine antiserum treatment compared to non-treated animals. This effect depended upon antiserum dilution. Interestingly, higher antiserum dilutions (1:40 and 1:200) significantly decrease serum venom levels but not splenic venom levels. These findings could be related to a differential distribution of ovine antivenom among serum and the other organs, as has been described for horse antiserum $(9,17)$.

This assay was then used to evaluate venom concentration in samples from BALB/C female mice injected with bothropic venom by two distinct routes (IP or ID). LD $_{50}$ was established previously by IP route (not shown). The decision to compare venom levels associated with both envenomation routes was based on the fact that IP route is classically employed in envenoming studies whereas ID route best resembles the natural ophidian accident. As expected, serum venom levels were always higher in animals envenomed by IP route. These results are in accordance with the differential severity of the two envenoming procedures. Animals injected by IP route presented more severe envenomation signs as prostration, hemorrhage at the peritoneal cavity and elevated mortality at 6 hours (results not shown). These findings resemble and reinforce clinical data showing a direct correlation between severity of clinical signs and the higher serum venom levels found in human patients $(2,5)$.

The profile of venom concentrations in spleen homogenates was very similar to blood venom distribution, i.e., significantly higher levels associated with IP route. However, these values did not consider the dilution of spleen homogenates determined by addition of $500 \mu \mathrm{l}$ of RPMI 1640 medium to the spleen to prepare the homogenates and use of $100 \mu \mathrm{l}$ to evaluate venom concentration. If these values were roughly corrected by this factor, they would be similar to blood levels. Certainly, this kind of determination could be better appraised by using homogenate samples from animals previously subjected to perfusion as described by Domingos et al. (16). Urine venom levels also followed the serum levels profile, i.e., higher levels in animals injected by IP route. However, these levels were not statistically different from levels determined by ID envenomation. 
Taken together, the results demonstrate that the optimized ELISA was adequate to evaluate venom levels in different samples and that this assay could also be useful to evaluate the neutralizing effect of antibothropic serum raised in ovines.

\section{ACKNOWLEDGEMENTS}

The authors thank the Center for the Study of Venoms and Venomous Animals (CEVAP, UNESP, Botucatu) for their generous supply of lyophilized $B$. jararaca venom and the Tropical Diseases Department for horse $F\left(a b^{\prime}\right)_{2}$ anti-venom donation.

\section{REFERENCES}

1 AUDEBERT F., SORKINE M., BON C. Envenoming by viper bites in France: clinical gradation and biological quantification by ELISA. Toxicon, 1992, 30, 599-609.

2 AUDEBERT F., SORKINE M., ROBBE-VINCENT A., BON C. Viper bites in France: clinical and biological evaluation; kinetics of envenomations. Hum. Exp. Toxicol., 1994, 13, 683-8.

3 BARRAL-NETTO M., SCHRIEFER A., VINHAS V., ALMEIDA AR. Enzyme-linked immunosorbent assay for the detection of Bothrops jararaca venom. Toxicon, 1990, 28, 1053-61.

4 BARRAVIERA B., SARTORI A., PEREIRA DA SILVA MF., KANENO R., PERAÇOLI MTS. Use of an ELISA assay to evaluate venom, antivenom, IgG and IgM human antibody levels in serum and cerebrospinal fluid from patients bitten by Crotalus durissus terrificus in Brazil. J. Venom. Anim. Toxins, 1996, 2, 14-27.

5 BARRAVIERA, B. Acidentes por serpentes do gênero Bothrops, Micrurus e Lachesis. In: MEIRA DA. Clínica de Doenças Tropicais e Infecciosas. Rio de Janeiro: Interlivros, 1991: 465-75.

6 BARRAVIERA B., GARCIA FCM., FULINI DR., MARCONDES-MACHADO J., MENDES RP., PEREIRA PCM., SOUZA LR., ZORNOFF DCM., MEIRA DA. Estudo clínico-epidemiológico de doentes picados por serpentes venenosas na região de Botucatu - SP. J. Bras. Med., 1994, 67, 224-32.

7 BOLAÑOS R., CERDAS L. Production and control of antivenin sera in Costa Rica. Bol. Oficina Sanit. Panam., 1980, 88, 189-96. 
8 BRASIL. Ministério da Saúde. Secretaria Nacional de Ações Básicas de Saúde. Acidentes ofídicos: contribuição ao estudo da morbidade. Brasília, 1998, p. 131.

9 CALDERON-ARANDA ES., RIVIERE G., CHOUMET V., POSSANI LD., BON C. Pharmacokinetics of the toxic fraction of Centruroides limpidus limpidus venom in experimentally envenomed rabbits and effects of immunotherapy with specific $\mathrm{F}$ $\left(\mathrm{ab}^{\prime}\right)_{2}$. Toxicon, 1999, 37, 771-82.

10 CHAVEZ-OLORTEGUI C., FONSECA SC., CAMPOLINA D., AMARAL CF., DINIZ CR. ELISA for the detection of toxic antigens in experimental and clinical envenoming by Tityus serrulatus scorpion venom. Toxicon, 1994, 32, 1649-56.

11 CHAVEZ-OLORTEGUI C., LOPES CS., CORDEIRO FD.,GRANIER C., DINIZ CR. An enzyme-linked immunosorbent assay (ELISA) that discriminates between Bothrops atrox and Lachesis muta muta venoms. Toxicon, 1993, 31, 417-25.

12 ChaVEZ-OlORTEgUI C., PENAFORTE CL., SILVA RR., FERREIRA AP., REZENDE NA., AMARAL CF., DINIZ CR. An enzyme-linked immunosorbent assay (ELISA) that discriminates between the venoms of Brazilian Bothrops especies and Crotalus durissus. Toxicon, 1997, 35, 253-60.

13 CHAVES F., LORIA GD., SALAZAR A., GUTIERREZ JM. Intramuscular administration of antivenoms in experimental envenomation by Bothrops asper: comparison between Fab and IgG. Toxicon, 2003, 41, 237-44.

14 CHIPPAUX JP., GOYFFON M. Producers of antivenom sera. Toxicon, 1983, 21 , 739-52.

15 CHIPPAUX JP., GOYFFON M. Venoms, antivenoms and immunotherapy. Toxicon, 1998, 36, 823-46.

16 DOMINGOS MO., TAKEHARA HA., LAING G., SNOWDEN KF., SELLS PG., MOTA I., THEAKSTON RD. Detection and neutralization of $B$. jararaca venom in mice. Braz. J. Med. Biol. Res., 1994, 27, 2613-22.

17 GUTIERREZ JM., LEON G., LOMONTE B. Pharmacokinetic-pharmacodynamic relationships of immunoglobulin therapy for envenomation. Clin. Pharmacokinet., 2003, 42, 721-41. 
18 LABROUSSE H., NISHIKAWA AK., BON C., AVRAMEAS S. Development of a rapid and sensitive enzyme-linked immunosorbent assay (ELISA) for measuring venom antigens after an experimental snake bite. Toxicon, 1988, 26, 1157-67.

19 LEON G., VALVERDE JM., ROJAS G., LOMONTE B., GUTIERREZ JM. Comparative study on the ability of IgG and Fab sheep antivenoms to neutralize local hemorrhage, edema and myonecrosis induced by Bothrops asper (terciopelo) snake venom. Toxicon, 2000, 38, 233-44.

20 ROSENFELD G. Symptomatology, pathology and treatment of snake bites in South America. In: BUCHERL W., BUCKLEY EE., DEULOFEU V. Eds. Venomous Animals and Their Venoms, vol. II. New York: Academic Press, 1971: 345-84.

21 SJOSTROM L., AL-ABDULLA IH., RAWAT S., SMITH DC., LANDON J. A comparison of ovine and equine antivenoms. Toxicon, 1994, 32, 427-33.

22 THEAKSTON RD., LLOYD-JONES MJ., REID HA. Micro-ELISA for detecting and assaying snake venoms and venom antibody. Lancet, 1977, 2, 639-41.

23 THEAKSTON RD., REID HA., LARRICK JW., KAPLAN J., YOST JA. Snake venom antibodies in Ecuadorian Indians. J. Trop. Med. Hyg., 1981, 84, 199-202.

24 THEAKSTON RD., WARRELL DA. Antivenoms: a list of hyperimmune sera currently available for the treatment of envenoming by bites and stings. Toxicon, 1991, 29, 1419-70.

25 WORLD HEALTH ORGANIZATION. Progress in the characterization of venoms and standardization of antivenoms. Geneva: World Health Organization, 1981. 44 p. (WHO offset Publication, 58). 